\title{
Validation of multiplex PCR for the diagnosis of acute bacterial meningitis in culture negative cerebrospinal fluid
}

\author{
Validação do PCR multiplex para o diagnóstico de meningite bacteriana aguda com \\ cultura de liquido cefalorraquidiano negativa \\ Sérgio Monteiro DE ALMEIDA',2; Libera Maria DALLA COSTA ${ }^{3,4}$, Christian SIEBRA ${ }^{5}$, Lavinia Nery Villa \\ Stangler AREND ${ }^{5}$, Keite da Silva NOGUEIRA6,7
}

\begin{abstract}
This study evaluated the operational characteristics of the multiplex polymerase chain reaction (PCR) for cerebrospinal fluid (CSF) from patients with cellular and biochemical characteristics of acute bacterial meningitis and positive or negative CSF cultures. Methods: Multiplex PCR was performed for 36 CSF samples: culture-proven acute bacterial meningitis $(n=7)$, culture-negative acute bacterial meningitis $(n=17)$, lymphocytic meningitis $(n=8)$, and normal CSF $(n=4)$. The operational characteristics of multiplex PCR were evaluated with definite and probable bacterial meningitis, using culture positive, cytological and biochemical CSF characteristics as the gold standard. Results: Multiplex PCR for CSF was efficient in the group with CSF cellular and biochemical characteristics of acute bacterial meningitis but with a negative CSF culture. This group demonstrated high specificity, positive predictive value, and efficiency. Conclusions: Multiplex PCR for CSF can improve the speed and accuracy of acute bacterial meningitis diagnosis in a clinical setting as a complement to classical immunological and bacteriological assays in CSF. It is also useful for CSF culture-negative acute bacterial meningitis.
\end{abstract}

Keywords: Cerebrospinal fluid; meningitis; meningitis, bacterial; polymerase chain reaction.

\section{RESUMO}

Este estudo avaliou as características funcionais da reação em cadeia da polimerase (PCR) multiplex para amostras de líquido cefalorraquidiano (LCR) de pacientes com características celulares e bioquímicas de meningite bacteriana aguda e culturas de LCR positivas ou negativas. Métodos: O PCR multiplex foi realizado em 36 amostras de LCR: meningite bacteriana aguda comprovada por cultura $(n=7)$, meningite bacteriana aguda com cultura negativa $(n=17)$, meningite linfocítica $(n=8)$ e LCR normal $(n=4)$. As características funcionais do PCR multiplex foram avaliadas para meningite bacteriana definitiva e provável, utilizando cultura positiva, características citológicas e bioquímicas do LCR como padrão-ouro. Resultados: O PCR multiplex do LCR foi eficiente no grupo com características celulares e bioquímicas do LCR de meningite bacteriana, mas com cultura do LCR negativa. Este grupo demonstrou especificidade, valor preditivo positivo e eficiência altos. Conclusões: Os autores concluíram que o PCR multiplex do LCR pode melhorar a velocidade e a precisão do diagnóstico de meningite bacteriana em um ambiente clínico como complemento aos ensaios imunológicos e bacteriológicos clássicos no LCR. Também é útil para meningite bacteriana aguda com cultura de LCR negativa.

Palavras-chave: Líquido cefalorraquidiano; meningite; meningite bacteriana; reação em cadeia da polimerase.

Acute bacterial meningitis is a medical emergency, with a delay in initiating effective antimicrobial therapy resulting in increased morbidity and mortality. Neisseria meningitidis,
Streptococcus pneumoniae, and Haemophilus influenzae type $\mathrm{b}$ are the main etiologic agents of acute community-acquired meningitis ${ }^{1}$.

\footnotetext{
'Universidade Federal do Paraná, Complexo Hospital de Clínicas, Ambulatório de Neuroinfecção, Curitiba PR, Brasil;

${ }^{2}$ Universidade Federal do Paraná, Complexo Hospital de Clínicas, Laboratório de Virologia, Curitiba PR, Brasil;

${ }^{3}$ Faculdades Pequeno Príncipe, Curitiba PR, Brasil;

${ }^{4}$ Instituto de Pesquisa Pelé Pequeno Príncipe, Curitiba PR, Brasil;

${ }^{5}$ Laboratório Central do Estado do Paraná, Laboratório de Bacteriologia, Curitiba PR, Brasil;

${ }^{6}$ Universidade Federal do Paraná, Complexo Hospital de Clínicas, Laboratório de Bacteriologia, Curitiba PR, Brasil;

7Universidade Federal do Paraná, Departamento de Patologia, Curitiba PR, Brasil.

Sérgio Monteiro de Almeida iD https://orcid.org/0000-0001-5690-105X
}

Correspondence: Sérgio Monteiro de Almeida; Hospital de Clínicas-UFPR, Seção de Virologia, Unidade Laboratório de Análises Clínicas; Rua Padre Camargo, 280; 80060-240 Curitiba PR, Brasil; E-mail: sergio.ma@ufpr.br

Conflict of interest: There is no conflict of interest to declare.

Received 23 October 2018; received in final form 29 November 2018; Accepted 07 December 2018. 
Clinical features alone cannot determine whether meningitis is present. Therefore, when meningitis is clinically suspected, the performance of a lumbar puncture is obligatory. The cerebrospinal fluid (CSF) examination is essential to establish the diagnosis and to identify the etiologic agent and its antibiotic sensitivity ${ }^{2,3,4}$.

An accurate and rapid diagnosis plays a crucial role in the treatment, prevention, and prognosis of bacterial meningitis; however, this is not always possible. Rapid methods such as Gram staining or latex agglutination testing (LAT) are available for the detection of certain agents but are not sufficiently sensitive. The definite laboratory diagnosis of bacterial meningitis requires the isolation of bacteria by the culture of CSF, which takes at least 12 to 48 hours. In addition, around 50\% of suspected cases of bacterial meningitis are not confirmed by culture, mainly because of pre-analytical problems and low clinical sample quality due to delayed sample processing and/or the use of antibiotics before the lumbar puncture ${ }^{5}$.

The standardization of a molecular biology technique to identify major etiological agents of bacterial meningitis will contribute to improvements in the diagnosis, especially in cases where there is a low concentration of the microorganism, the patient is already being treated with antimicrobials, or when culture results are not satisfactory ${ }^{1,6}$.

This study adds to the contributions of previous studies $^{7}$ by further investigating the accuracy of a multiplex polymerase chain reaction (PCR) assay for acute bacterial meningitis on a substantial number of CSF samples from patients with suspected bacterial meningitis based on CSF cellular and biochemical characteristics but with negative CSF cultures, as well as cases with proven bacterial meningitis and positive CSF culture results.

\section{METHODS}

\section{Subjects and sample collection}

This study was approved by the Institutional Research Review Board of the Complex Hospital of Clinics, Federal University of Paraná (CHC-UFPR), Brazil. The authors confirm that they have complied with the World Medical Association Declaration of Helsinki regarding ethical conduct of research involving human subjects.

All CSF samples were collected for clinical purposes by lumbar puncture. The CSF samples from patients suspected to have acute meningitis (bacterial and viral) were selected randomly based on CSF cellular, biochemical and microbiological (culture) characteristics (Figure 1). Samples from newborns, post-neurosurgery samples, or samples from patients with a previous antibiotic history were excluded.

Data regarding the biochemical and cytological analysis of CSF, as well as the epidemiological data of patients were obtained from the laboratory computer records.

A total of 36 CSF samples, collected in the period August to November 2011, were included in this study. The samples were distributed in the following groups:

1) Group 1: Definite acute bacterial meningitis $(n=7)$. Acute bacterial meningitis identified by culture: Haemophilus sp. (1 case), Listeria monocytogenes (2 cases), $N$. meningitidis (2 cases), and S. pneumoniae (2 cases).

2) Group 2: Probable acute bacterial meningitis with negative CSF culture $(\mathrm{n}=17)$. Cytological and biochemical characteristics of acute bacterial meningitis in the $\mathrm{CSF}^{3}$ : increase of white blood cells (WBC) ( $>5$ cells $/ \mathrm{mm}^{3}$ ), predominance of neutrophils, glucose $<45 \mathrm{mg} / \mathrm{dL}$, lactate $>3.5$ $\mathrm{mmol} / \mathrm{L}$, and bacteria not identified by culture.

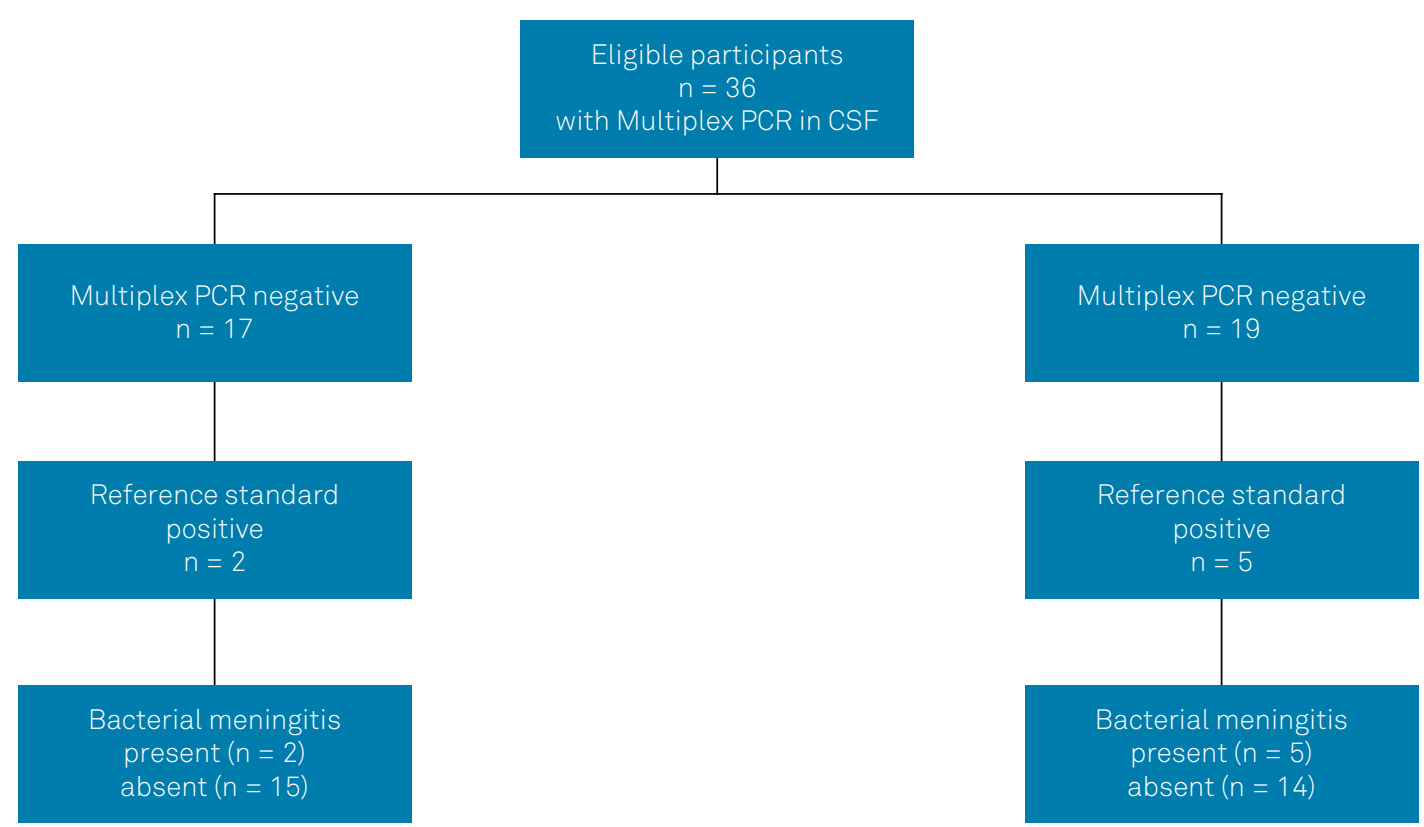

Figure 1. Standards for Reporting of Diagnostic Accuracy Studies flow diagram of participants through the validation of multiplex PCR (index test), for the diagnosis of bacterial meningitis in cerebrospinal fluid (CSF) samples, reference standard CSF culture (solid medium). 
3) Group 3: CSF with cytological and biochemical characteristics of lymphocytic meningitis, possible viral meningitis ${ }^{3}(n=8)$ : increased number of WBC ( $>5$ cells $/ \mathrm{mm}^{3}$ ), predominance of lymphocytes, glucose $\geq$ $45 \mathrm{mg} / \mathrm{dL}$, lactate $<3.5 \mathrm{mmol} / \mathrm{L}$. Viruses were not identified in any CSF sample.

4) Group 4: CSF with normal cellular and biochemical characteristics $(n=4): W B C \leq 5$ cells $/ \mathrm{mm}^{3}$, glucose $\geq 45 \mathrm{mg} / \mathrm{dL}$, lactate $<3.5 \mathrm{mmol} / \mathrm{L}^{3}$.

The epidemiological, CSF cytology and biochemical characteristics of the groups studied are shown in Table 1.

\section{Traditional and immunological microbiological diagnostic tests for bacteriology}

All CSF samples were subjected to direct microscopic examination (Gram stain smear) and culturing. The CSF specimens were inoculated onto agar plates ( $5 \%$ sheep blood agar and supplemented chocolate agar plates) and incubated at $37^{\circ} \mathrm{C}$ for 24 to 48 hours. For positive cultures, bacteria were identified using a VITEK 2 Compact System (BioMérieux Vitek, Inc., Hazelwood, MO, USA).

Latex agglutination testing for acute meningitis (BioMérieux Vitek, Inc.) was carried out per manufacturer's instructions.

\section{Meningitis multiplex PCR}

Extraction of DNA was performed using a Biopur DNA extraction kit. All samples were subjected to multiplex PCR for bacterial meningitis using the Seeplex Meningitis-B ACE Detection Kit (Seegene Inc., Seoul, Korea), following the manufacturer's recommendations. This assay detects five species of bacteria that cause meningitis, S. pneumoniae (gene gyrB), H. influenzae (P6), N. meningitidis (ctrA), S. agalactiae (Cfb), L. monocytogenes (Hly) within six hours.

\section{CSF biochemistry and cytology}

The CSF total protein was determined by benzethonium chloride (Architect, Abbott, IL, USA), total glucose by hexokinase/G-6-PDH (Architect), lactate by amperometry (RAPIDPoint 500, Siemens, NY, USA). The total $\mathrm{WBC} / \mathrm{mm}^{3}$ was quantified in fresh, uncentrifuged CSF by manual counting in a Fuchs-Rosenthal chamber. Pleocytosis in the CSF was defined as leukocytes $>5$ cells $/ \mathrm{mm}^{3}$. For differential leukocyte counts, CSF samples were concentrated using the Shandon Cytospin (Pittsburgh, PA, USA). The slides were then stained by the May-Grünwald Giemsa technique.

\section{Evaluation of operational characteristics of multiplex PCR in CSF for bacterial meningitis}

The operational characteristics of the multiplex PCR in CSF (index test) for acute bacterial meningitis were evaluated using positive CSF cultures (definite bacterial meningitis) and/or a probable acute bacterial meningitis sample, defined by cytological and biochemical CSF characteristics as the reference (gold) standard.

The following performance parameters were evaluated: sensitivity, specificity, accuracy (efficiency), positive predictive value (PPV), negative predictive value (NPV), Youden's index $(\mathrm{J})=[($ sensitivity + specificity $)-1]$, false positive $(\mathrm{FP})$ rate $(\%)=100-\mathrm{PPV}$, presumptive positive $=($ true positive $(\mathrm{TP})$ $+\mathrm{FP}) /$ total, detection rate $=\mathrm{TP} /$ total, error ratio $=(\mathrm{FP}+$ false negative $(\mathrm{FN})) / \mathrm{TP}$, combined error $=\mathrm{FP}+\mathrm{FN} /$ total $^{8}$. Clinical utility index $+(\mathrm{CUI}+)$ to rule in, PPV $\times$ sensitivity; clinical utility index - (CUI-) to rule out (screening), NPV $\times$ specificity. The CUI was classified as utility excellent $\geq 0.81$, good $\geq 0.64$, fair $\geq 0.49$, poor $\leq 0.49$, and very poor $\leq 0.36^{9,10}$. The positive likelihood ratio $(\mathrm{LR}+)$ and negative likelihood ratio (LR-) were also determined. An LR+ of 10.0 or more indicated

Table 1. Epidemiological, cytological and biochemical characteristics in cerebrospinal fluid of all the groups studied.

\begin{tabular}{|c|c|c|c|c|c|}
\hline Variable & Group 1 & Group 2 & Group 3 & Group 4 & $p$-value \\
\hline$N$ & 7 & 17 & 8 & 4 & - \\
\hline Age, years & $43(2 ; 66.5)$ & $12(2 ; 47)$ & $15(3.8 ; 46)$ & $24(4 ; 40)^{1}$ & 0.940 \\
\hline Male, n (\%) & $5 / 7(71)$ & $10 / 17(59 \%)$ & $5 / 8(63 \%)$ & $2 / 4(50 \%)$ & 0.904 \\
\hline $\mathrm{RBC}$, cells $/ \mathrm{mm}^{3}$ & $140(12,5 ; 1880)$ & $295(82.5 ; 2215)$ & $106(1.85 ; 417)$ & $223(4.6 ; 2500)^{1}$ & 0.331 \\
\hline WBC, cells $/ \mathrm{mm}^{3}$ & $975(543 ; 4731)$ & $480(170 ; 2640)$ & $61(33 ; 105)$ & $1.5(0.3 ; 4.7)^{1}$ & 0.0002 \\
\hline Neutrophils, \% & $79(61 ; 96)$ & $79(66 ; 93)$ & $4.0(2.5 ; 16)$ & - & 0.0004 \\
\hline Lymphocytes, \% & $16(3 ; 28)$ & $21(4.5 ; 28)$ & $86(70 ; 94.5)$ & - & 0.0003 \\
\hline Glucose, mg/dL & $4.8(2 ; 18.3)$ & $40(5 ; 61)$ & $58(52 ; 63)$ & $76.5(65 ; 92.0)^{1}$ & 0.002 \\
\hline CSF/serum Glucose & - & $0.88(0.02 ; 0.89)^{1}$ & $0.55(0.53 ; 0.73)$ & $0.73(0.55 ; 1.0)^{1}$ & 0.410 \\
\hline Total Protein, mg/dL & $245(227 ; 1431)$ & $218(41 ; 345)$ & $54(29.7 ; 84)$ & $42.5(25 ; 54)^{1}$ & 0.039 \\
\hline Lactate, $\mathrm{mmol} / \mathrm{L}$ & - & $3.9(2.2 ; 13.4)^{1}$ & $2.1(1.8 ; 2.7)$ & $1.6(1.3 ; 2.0)^{1}$ & 0.024 \\
\hline Gram & $5(71 \%)$ & $2(12 \%)$ & 0 & 0 & - \\
\hline LAT n (\%) & $3(43 \%)$ & $6(35 \%)$ & 0 & 0 & - \\
\hline Multiplex PCR n (\%)² & $5(71 \%)$ & $11(65 \%)$ & $3(38 \%)$ & 0 & 0.067 \\
\hline
\end{tabular}

RBC: red blood cells; WBC: white blood cells; Data presented in median (IQR) or n (\%) as appropriate; ${ }^{1}:$ min, max; ${ }^{2}:$ G1xG2; $p=1.0 ;$ : LAT: latex agglutination testing; PCR: polymerase chain reaction. Significant differences are highlighted in bold. 
that a positive test almost confirmed the disease, a value of approximately 6.0 indicated that the disease was present, and a value of approximately 1.0 indicated that the test could not show if there was disease or not ${ }^{11,12}$. An LR+ of 0.1 or less meant that the disease was practically absent.

The post-test probability for a positive test and for a negative test was calculated using the Fagan's nomogram ${ }^{13,14}$.

\section{Statistical analysis}

Categorical variables were compared between groups using Fisher's exact test; continuous variables were compared with the Mann-Whitney or Kruskal-Wallis test for nonparametric data, as appropriate. Results were considered statistically significant at the $5 \%$ alpha level.

The concordance between the different methods to detect the etiological agent for bacterial meningitis in all the groups was determined by the Kappa statistic, where complete agreement corresponds to kappa $=1$, and lack of agreement (i.e. purely random coincidences of rates) corresponds to kappa $=0$.

\section{RESULTS}

Among the group with definite acute bacterial meningitis (Group 1), five were also positive by multiplex PCR for N. meningitidis $(\mathrm{n}=2)$, S. pneumoniae $(\mathrm{n}=2)$, or $H$. influenzae $(\mathrm{n}=1)$. Two samples were negative by multiplex PCR but positive for L. monocytogenes on CSF culture. In Group 2, 11 culture-negative samples were multiplex PCR positive for S. pneumoniae (n $=4), N$. meningitidis $(\mathrm{n}=6)$, or S. agalactiae $(\mathrm{n}=1)$; in Group 3, three samples were multiplex PCR positive for $S$. pneumoniae.
Gram staining was positive and multiplex PCR was negative in two cases, with one sample showing Gram-positive bacilli, which in culture was identified as L. monocytogenes (Group 1), and another showing Gram-negative bacilli (Group 2).

All cases positive by LAT were in concordance with multiplex PCR results. Multiplex PCR was positive and latex negative in seven cases: $N$. meningitidis $(\mathrm{n}=3), S$. pneumoniae $(\mathrm{n}=2)$, Haemophilus sp. $(\mathrm{n}=1)$, S. agalactiae $(\mathrm{n}=1)$.

\section{Operational characteristics of multiplex PCR for CSF of acute bacterial meningitis}

The sensitivity and NPV of the multiplex PCR assay for the group with definite bacterial meningitis were high at $71.4 \%$ and $88.2 \%$, respectively, whereas for the group with CSF cellular and biochemical characteristics of bacterial meningitis, but with negative culture results, the sensitivity decreased to $64.7 \%$, although the specificity increased to $75.0 \%$, the PPV to $78.6 \%$, and the efficiency increased to $69.0 \%$. The association of well-established diagnostic methods, chiefly culture with LAT, showed the highest sensitivity $(84.6 \%)$ and efficiency $(72 \%)$.

The positive likelihood ratios of all groups studied were greater than 1 , indicating that the test result was associated with the presence of disease.

The operational characteristics of multiplex PCR for CSF samples of acute bacterial meningitis are shown in Table 2.

The post-test probabilities for a positive and a negative test calculated by the Fagan's nomogram for the multiplex PCR assay on CSF for bacterial meningitis in the groups studied are shown in Figure 2A-D. The groups that showed the highest increase in the post-test probability for a positive test were the group that had positive CSF cultures for bacteria

Table 2. Performance characteristics of multiplex PCR assay for the diagnosis of acute community-acquired bacterial meningitis.

\begin{tabular}{|c|c|c|c|c|}
\hline Meningitis & Definite $^{1}$ & $\begin{array}{c}\text { Culture + and / } \\
\text { or LAT + }\end{array}$ & Probable $^{2}$ & $\begin{array}{c}\text { Definite + } \\
\text { Probable }\end{array}$ \\
\hline$N$ & 7 & 13 & 17 & 24 \\
\hline TP & 5 & 11 & 11 & 16 \\
\hline Sensitivity \% & 71.4 & 84.6 & 64.7 & 66.7 \\
\hline Specificity \% & 51.7 & 65.2 & 75.0 & 75.0 \\
\hline PPV \% & 26.3 & 57.9 & 78.6 & 84.2 \\
\hline NPV \% & 88.2 & 88.2 & 60.0 & 52.9 \\
\hline Efficiency \% (test score) & 55.6 & 72.2 & 69.0 & 69.4 \\
\hline Youden Index & 0.23 & 0.50 & 0.40 & 0.42 \\
\hline False + rate $\%$ & 73.7 & 42.1 & 21.4 & 15.8 \\
\hline Presumptive + \% & 52.8 & 52.8 & 48.3 & 52.8 \\
\hline Detection rate $\%$ & 71.4 & 84.6 & 64.7 & 66.7 \\
\hline Error rate & 3.2 & 0.91 & 0.82 & 0.69 \\
\hline Combined error & 0.44 & 0.28 & 0.31 & 0.31 \\
\hline LR+ & 1.48 & 2.43 & 2.59 & 2.67 \\
\hline LR- & 0.55 & 0.24 & 0.47 & 0.44 \\
\hline CUI+ & 0.19 & 0.49 poor & 0.51 fair & 0.56 \\
\hline CUI- & 0.46 & 0.58 fair & 0.45 poor & 0.40 \\
\hline
\end{tabular}

PCR: polymerase chain reaction; ${ }^{1}$ definite acute bacterial meningitis, CSF culture for bacteria positive; ${ }^{2}$ : probable acute bacterial meningitis, CSF culture for bacteria negative;TP: true positive; PPV: positive predictive value; NPV: negative predictive value; LR+: positive likelihood; LR-: negative likelihood; CUI+: Clinical utility +; CUI-: Clinical utility; LAT: latex agglutination testing. 

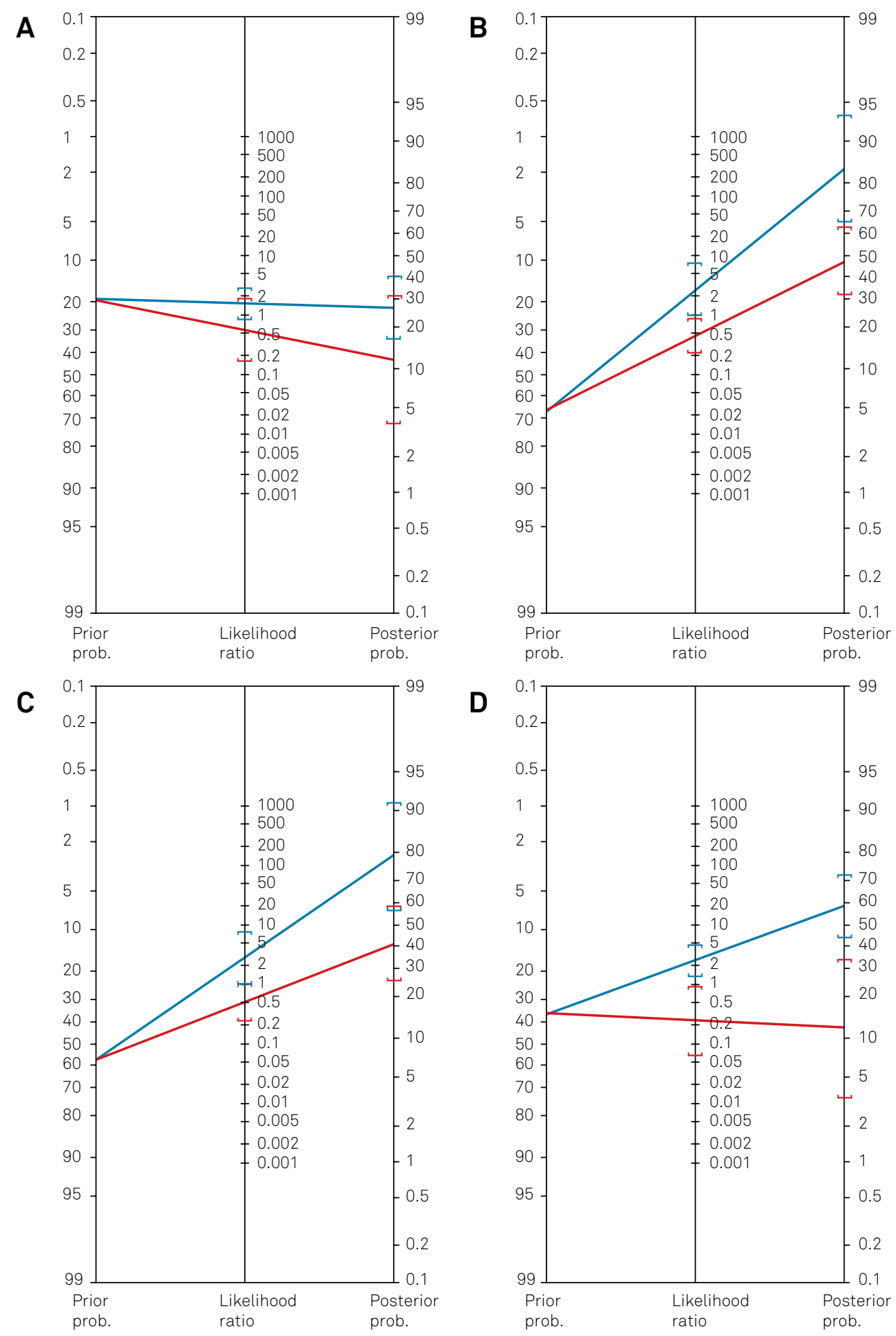

Figure 2. Fagan's nomogram showing the posterior probability for a positive (blue line), and for a negative (red line) test multiplex PCR assay in CSF for bacterial meningitis, in the groups studied. A. Group with definite meningitis. For a positive test: Positive Likelihood ratio [95\% confidence interval]: 1.48 [0.81; 2.70]; Posterior probability (odds): 26\% (0.4) [16\%; 39\%]; approximately 1 in 3.8 with positive test are sick. For a negative test: Negative Likelihood ratio: 0.55 [0.16; 1.88]. Posterior probability (odds): 12\% (0.1) [4\%; 31\%]; approximately 1 in 1.1 with negative test are well. B. Group definite plus probable meningitis. For a positive test: Positive Likelihood ratio [95\% confidence interval]: 2.67 [0.96; 7.40]; Posterior probability (odds): 84\% (5.3) [66\%; 94\%]; approximately 1 in 1.2 with positive test are sick. For a negative test: Negative Likelihood ratio: 0.44 [0.23; 0.85]; Posterior probability (odds): 47\% (0.9) [32\%; 63\%]; approximately 1 in 1.9 with negative test are well. C. Group with probable meningitis. CSF characteristics of bacterial meningitis but CSF culture for bacteria negative. For a positive test: Positive Likelihood ratio [95\% confidence interval]: 2.59 [0.91; 7.33]; Posterior probability (odds): 79\% (3.7) [56\%; 91\%]; approximately 1 in 1.3 with positive test are sick. For a negative test: Negative Likelihood ratio: 0.47 [0.23,0.97]; Posterior probability (odds):40\% (0.7) [25\%; 58\%]; approximately 1 in 1.7 with negative test are well. D. Association of CSF culture positive and latex. For a positive test: Positive Likelihood ratio:2.44\% [1.33; 4.46]; Posterior probability (odds): 58\% (1.4) [43\%; 72\%]; approximately 1 in 1.7 with positive test are sick. For a negative test: Negative Likelihood ratio: 0.25\% [0.06;0.87]; Posterior probability (odds):12\% (0.1), [3\%; 33\%]; approximately 1 in 1.1 with negative test are well. 
Table 3. Association of traditional microbiological methods with immunological and molecular biology methods in CSF for etiological diagnosis of acute bacterial meningitis in the groups, with CSF biochemistry and cell characteristics of acute bacterial meningitis with and without positive culture (Group 1 and 2, $n=24$ ).

\begin{tabular}{lcc}
\hline Microbiological methods in CSF & N & $\%$ \\
\hline Gram & 7 & 29.2 \\
\hline Culture & 7 & 29.2 \\
\hline LAT & 9 & 37.5 \\
\hline Multiplex PCR & 16 & 66.7 \\
\hline Gram; Culture & 9 & 37.5 \\
\hline Gram; Latex & 12 & 50.0 \\
\hline Gram; Multiplex PCR & 18 & 75.0 \\
Culture; LAT & 13 & 54.2 \\
\hline Culture; Multiplex PCR & 18 & 75.0 \\
\hline LAT; Multiplex PCR & 16 & 66.7 \\
Gram; Culture; LAT & 14 & 58.3 \\
\hline Gram; Culture; Multiplex PCR & 19 & 79.2 \\
\hline Gram; LAT; Multiplex PCR & 18 & 75.0 \\
\hline Culture; LAT; Multiplex PCR & 18 & 75.0 \\
\hline Gram; Culture; LAT; Multiplex PCR & 19 & 79.2 \\
\hline LAT: latex agglutination testing; PCR: polymerase chain reaction.
\end{tabular}

(definite) plus the group with CSF cellular and biochemical characteristics of acute bacterial meningitis but with a negative CSF culture result (probable meningitis); the posterior probability (odds) for a positive test was $84 \%$ (Figure 2B). The results of analyzing only the group with probable meningitis for a positive test result yielded a posterior probability (odds) of $79 \%$ (Figure 2C).

Likelihood ratios, positive or negative, are show in Table 3. Among the four groups studied, the most compelling argument for acute bacterial meningitis, was due to the greatest $\mathrm{LR}+$ in the groups with probable and the group with the association of definite and probable meningitis, which increased the probability of acute bacterial meningitis to $15-20 \%$ $(\mathrm{LR}+\geq 2.6)^{12}$. The four groups studied showed similar compelling arguments against the diagnosis of acute bacterial meningitis, because LR- values were close to zero, which reduced the probability of acute bacterial meningitis about $15-30 \%$.

\section{Association of traditional microbiological methods with immunological and/or molecular biology methods to identify etiological agents of acute bacterial meningitis in CSF}

Table 3 summarizes the positivity rate of the individual microbiological assays in CSF for the diagnosis of acute bacterial meningitis, as well as the association of traditional microbiological methods with immunological and/or molecular biology methods, in the groups with CSF biochemical and cellular characteristics of acute bacterial meningitis with and without culture positivity (Groups 1 and 2, $n=24$ ).
An increased positivity rate was observed when several methods were used together, mainly the traditional microbiological methods with multiplex PCR.

\section{Concordance between multiplex PCR in CSF and traditional bacteriological methods or the latex agglutination test (Kappa statistics)}

For CSF multiplex PCR and culture, concordance was observed for 20 CSF samples (55.6\%), resulting in a kappa index of 0.14 , standard deviation (SD) of 0.16 , and $95 \%$ confidence interval ( $95 \% \mathrm{CI}$ ) of -0.174 to 0.54 , showing poor concordance. Two cases with positive CSF culture for L. monocytogenes were multiplex PCR negative.

In terms of results for CSF multiplex PCR and LAT in CSF (Groups 1 and 2), there was concordance in 17 CSF samples (70.8\%), with a kappa index of 0.46 , SD of 0.17 , and a CI $95 \%$ of 0.126 to 0.797 , showing moderate concordance. No cases were LAT positive and multiplex PCR negative.

Data analysis for CSF multiplex PCR and Gram staining smear results in CSF (Groups 1 and 2), showed concordance in 12 CSF samples (50\%), with a kappa index 0.15 , SD of 0.17 , and CI $95 \%$ of -0.193 to 0.489 ), showing poor concordance. The only bacteria identified by Gram staining smear with negative multiplex PCR results, were Gram-negative bacilli (one case).

\section{DISCUSSION}

This study aimed to evaluate the operational characteristics of multiplex PCR for CSF samples, with negative bacterial cultures (possible bacterial meningitis) and positive cultures (definite bacterial meningitis). Multiplex PCR on CSF was an efficient method in all groups studied. In the group with CSF cellular and biochemical characteristics of acute bacterial meningitis but negative culture for bacteria, the specificity, PPV, and efficiency were high; however, in the culture-positive group (definite) the sensitivity and NPV were high. The concurrent use of etiological diagnostic methods, chiefly culture and LAT, showed the highest sensitivity and efficiency. The positive likelihood ratios of all groups studied were greater than 1 , indicating that the test results were associated with the presence of disease.

We showed that multiplex PCR had poor diagnostic ability for culture-proven meningitis by L. monocytogenes, although the number of cases was too small to allow a definite conclusion. Another study that evaluated the accuracy of PCR in comparison to conventional methods for the diagnosis of $L$. monocytogenes from different clinical specimens and food stuffs showed low accuracy ${ }^{15}$. L. monocytogenes meningitis is uncommon in the general population, but it is a severe infection in neonates and the elderly, immunocompromised, pregnant, and cancer patients ${ }^{16}$.

The development of rapid etiological diagnostic methods for acute bacterial meningitis is crucial. Gram staining and 
LAT are point-of-care diagnostic tests; however, both have important limitations in terms of sensitivity and specificity. The CSF culture remains the diagnostic gold standard for detection of pathogens in CSF specimens, although it takes 12 to 48 hours for a definite diagnosis, has severe limitations for samples from patients who previously received antibiotics, and depends largely on the quality of the sample sent to the laboratory ${ }^{17}$. Traditional bacteriological methods have low sensitivity for the etiologic diagnosis of acute bacterial meningitis. The performance of direct bacterioscopic examination through Gram staining is obligatory for all CSF samples with a suspicion of bacterial meningitis, as it is a simple and very effective procedure ${ }^{18}$. The probability of visualizing bacteria in CSF samples that have undergone Gram staining depends on the quality of the smear preparation. The bacterial concentration is directly related to the sensitivity of the direct bacterioscopic examination; the percentage of positive samples is $25 \%$ when the concentration is less than or equal to $10^{3} \mathrm{CFU} / \mathrm{mL}$, and it increases to $60 \%$ with $10^{3}-10^{5} \mathrm{CFU} / \mathrm{mL}$ and $97 \%$ with more than $10^{5} \mathrm{CFU} / \mathrm{mL}^{19,20,21}$.

Newer technologies, such as multiplex PCR, may help provide a quicker and more accurate diagnosis ${ }^{1}$. There has been much interest in the development of standardized molecular tests for the diagnosis of meningitis ${ }^{22}$. Molecular biological methods are important alternatives, and multiplex technology was a great advance in the basic PCR technique. Multiplex PCR can be helpful as an associated method, with the main limitations including the presence of inhibitory factors such as DNAse and the necessity to collect the samples in DNAse-free vials. Alternative methods of molecular identification, including 16S/23S rRNA gene amplification, followed by sequencing and real time PCR, have been developed $^{7}$. Several multiplex PCR assays for the simultaneous detection of S. pneumoniae, $H$. influenzae, and $N$. meningitidis have been established ${ }^{22,23,24,25,26}$. However, their application as a first-line diagnostic test remains controversial ${ }^{25,26,27}$.

If the lumbar puncture is delayed until after antibiotics have been given, the likelihood of identifying an organism may be reduced by up to $44 \%^{28,29}$. Molecular methods are, therefore, becoming increasingly important for diagnosis. The most common of these is PCR, which can detect organisms in blood or CSF for several days after antibiotics have been given ${ }^{30,31}$. This method has high sensitivity $(87-100 \%)$ and specificity $(98-100 \%)^{32,33,34,35}$. There has been much interest in the ability to detect multiple pathogens with one platform, such as multiplex PCR and 16S rRNA PCR ${ }^{36,37}$. The 16S rRNA gene is present in almost all bacteria; one meta-analysis ${ }^{38}$ has shown $16 \mathrm{~S}$ rRNA PCR to be both sensitive and specific for the diagnosis of bacterial meningitis compared with standard culture (pooled sensitivity of $92 \%$ and specificity of $94 \%^{1}$.

The UK Joint Specialist Societies guideline on the diagnosis and management of acute meningitis in immunocompetent adults recommends that CSF PCR for pneumococcal and meningococcal sepsis should be performed in all cases of suspected bacterial meningitis ${ }^{6}$.

Disadvantages of PCR compared to CSF culture include the lack of an isolate on which traditional antimicrobial susceptibility testing can be performed. There are PCR assays now available for both serogrouping and serotyping, which can be used for surveillance and vaccine evaluation ${ }^{24}$. There are differences in the accuracy of PCR for different bacteria causing meningitis, with the sensitivity of PCR on CSF in bacterial meningitis calculated as $61-100 \%$ for S. pneumoniae, 88-94\% for N. meningitidis, and 72-92\% for H. influenza $e^{22,39}$.

The present study is not free of limitations; the main limitation was the small number of culture positive CSF samples. The small number of samples with different bacteria identified limited the evaluation of the accuracy of multiplex PCR for each type of bacterium. In the group with lymphocytic meningitis suggestive of viral meningitis (Group 3), none of the CSF samples tested positive for virus by PCR. Three samples in this group were multiplex PCR positive for S. pneumoniae; these results were considered false positives, although classical CSF biochemistry and cell characteristics may not always be present in bacterial or viral meningitis. The CSF characteristics of bacterial meningitis can resemble viral meningitis, with predominance of lymphocytes, in partially-treated bacterial meningitis or immunosuppressed patients ${ }^{3}$.

In conclusion, multiplex PCR was shown to have a high specificity and negative predictive value, demonstrating the utility of this method in a clinical setting. Multiplex PCR should be used as a complement to classical bacteriological methods, as well as conventional microscopy, culture methods, and clinical algorithms. Multiplex PCR of the CSF proved to be a valuable method for improving the rapidity and accuracy of a diagnosis of bacterial meningitis, even in cases with CSF cytochemical characteristics of acute bacterial meningitis but negative culture results.

\section{References}

1. McGill F, Heyderman RS, Panagiotou S, Tunkel AR, Solomon T. Acute bacterial meningitis in adults. Lancet. 2016 De;388(10063):P3036-47. https://doi.org/10.1016/S0140-6736(16)30654-7

2. Practice parameters: lumbar puncture (summary statement). Report of the Quality Standards Subcommittee of the American Academy of Neurology. Neurology. 1993 Mar;43(3 Pt 1):625-7.

3. Fishman RA. Cerebrospinal fluid in diseases of the nervous system. Philadelphia: Saunders; 1993.
4. Klein JO, Feigin RD, McCracken GH Jr. Report of the task force on diagnosis and management of meningitis. Pediatrics. 1986 Nov;78(5 Pt 2 suppl.5):959-82.

5. Wagner K, Springer B, Pires VP, Keller PM. Pathogen identification by multiplex LightMix real-time PCR assay in patients with meningitis and culture-negative cerebrospinal fluid specimens. J Clin Microbiol. 2018 Jan;56(2):e01492-17. https://doi.org/10.1128/JCM.01492-17 
6. McGill F, Heyderman RS, Michael BD, Defres S, Beeching NJ, Borrow $\mathrm{R}$, et al. The UK joint specialist societies guideline on the diagnosis and management of acute meningitis and meningococcal sepsis in immunocompetent adults. J Infect. 2016 Apr;72(4):405-38. https://doi.org/10.1016/j.jinf.2016.01.007

7. Shin SY, Kwon KC, Park JW, Kim JM, Shin SY, Koo SH. Evaluation of the Seeplex ${ }^{\circledR}$ Meningitis ACE Detection kit for the detection of 12 common bacterial and viral pathogens of acute meningitis. Ann Lab Med. 2012 Jan;32(1):44-9. https://doi.org/10.3343/alm.2012.32.1.44

8. Galen RS, Gambino SR. Beyond normality: the predictive value and efficiency of medical diagnoses. New York: John Wiley \& Sons; 1975.

9. Mitchell AJ. The clinical significance of subjective memory complaints in the diagnosis of mild cognitive impairment and dementia: a meta-analysis. Int J Geriatr Psychiatry. 2008 Nov;23(11):1191-202. https://doi.org/10.1002/gps.2053

10. Mitchell AJ. Sensitivity $\times$ PPV is a recognized test called the clinical utility index (CUI+). Eur J Epidemiol. 2011 Mar;26(3):251-2. https://doi.org/10.1007/s10654-011-9561-x

11. Akobeng AK. Understanding diagnostic tests 2: likelihood ratios, pre- and post-test probabilities and their use in clinical practice. Acta Paediatr. 2007 Apr;96(4):487-91. https://doi.org/10.1111/j.1651-2227.2006.00179.x

12. McGee S. Simplifying likelihood ratios. J Gen Intern Med. 2002 Aug;17(8):646-9. https://doi.org/10.1046/j.1525-1497.2002.10750.x

13. Sackett DL, Haynes RB. The architecture of diagnostic research. BMJ. 2002 Mar;324(7336):539-41. https://doi.org/10.1136/bmj.324.7336.539

14. Fagan TJ. Letter: nomogram for Bayes theorem. N Engl J Med. 1975 Jul;293(5):257. https://doi.org/10.1056/NEJM197507312930513

15. Shalaby MA, Mohamed MS, Mansour MA, Abd El-Haffiz AS. Comparison of polymerase chain reaction and conventional methods for diagnosis of Listeria monocytogenes isolated from different clinical specimens and food stuffs. Clin Lab. 2011;57(11-12):919-24.

16. Mook P, O'Brien SJ, Gillespie IA. Concurrent conditions and human listeriosis, England, 1999-2009. Emerg Infect Dis. 2011 Jan;17(1):3843. https://doi.org/10.3201/eid1701.101174

17. Kanegaye JT, Soliemanzadeh P, Bradley JS. Lumbar puncture in pediatric bacterial meningitis: defining the time interval for recovery of cerebrospinal fluid pathogens after parenteral antibiotic pretreatment. Pediatrics. $2001 \mathrm{Nov}$;108(5):1169-74.

18. Hamoudi AC. Rapid diagnostic techniques for bacterial meningitis. Am J Med Technol. 1982 Oct;48(10):813-9.

19. Feldman WE. Concentrations of bacteria in cerebrospinal fluid of patients with bacterial meningitis. J Pediatr. 1976 Apr;88(4 Pt 1):54952. https://doi.org/10.1016/S0022-3476(76)80003-0

20. Feldman WE. Effect of prior antibiotic therapy on concentrations of bacteria in CSF. Am J Dis Child. 1978 Jul;132(7):672-4.

21. La Scolea LJ Jr, Dryja D. Quantitation of bacteria in cerebrospinal fluid and blood of children with meningitis and its diagnostic significance. J Clin Microbiol. 1984 Feb;19(2):187-90.

22. Leber AL, Everhart K, Balada-Llasat JM, Cullison J, Daly J, Holt $S$, et al. Multicenter evaluation of BioFire FilmArray meningitis/ encephalitis panel for detection of bacteria, viruses, and yeast in cerebrospinal fluid specimens. J Clin Microbiol. 2016 Sep;54(9):2251-61. https://doi.org/10.1128/JCM.00730-16

23. Corless CE, Guiver M, Borrow R, Edwards-Jones V, Fox AJ, Kaczmarski EB. Simultaneous detection of Neisseria meningitidis, Haemophilus influenzae, and Streptococcus pneumoniae in suspected cases of meningitis and septicemia using real-time PCR. J Clin Microbiol. 2001 Apr;39(4):1553-8. https://doi.org/10.1128/JCM.39.4.1553-1558.2001

24. Deutch S, Møller JK, Ostergaard L. Combined assay for two-hour identification of Streptococcus pneumoniae and Neisseria meningitidis and concomitant detection of 165 ribosomal DNA in cerebrospinal fluid by real-time PCR. Scand J Infect Dis. 2008;40(8):607-14. https://doi.org/10.1080/00365540801914833
25. Seth R, Murthy PS, Sistla S, Subramanian M, Tamilarasu K. Rapid and accurate diagnosis of acute pyogenic meningitis due to Streptococcus pneumoniae, Haemophilus influenzae type $b$ and Neisseria meningitides using a multiplex PCR assay. J Clin Diagn Res. 2017 Sep;11(9):FC01-04. https://doi.org/10.7860/JCDR/2017/28114.10532

26. Bașpınar EO, Dayan S, Bekçibașı M, Tekin R, Ayaz C, Deveci Ö, et al. Comparison of culture and PCR methods in the diagnosis of bacterial meningitis. Braz J Microbiol. 2017 Apr - Jun;48(2):232-6. https://doi.org/10.1016/j.bjm.2016.06.014

27. Schreckenberger PC, McAdam AJ. Large multiplex PCR panels should be first-line tests for detection of respiratory and intestinal pathogens. J Clin Microbiol. 2015 Oct;53(10):3110-5. https://doi.org/10.1128/JCM.00382-15

28. Michael B, Menezes BF, Cunniffe J, Miller A, Kneen R, Francis G, et al. Effect of delayed lumbar punctures on the diagnosis of acute bacterial meningitis in adults. Emerg Med J. 2010 Jun;27(6):433-8. https://doi.org/10.1136/emj.2009.075598

29. Nemescu RE, lancu LS, Dorneanu OS, Ursu RG, Dorobăt CM. Influence of antibiotic therapy prior to admission on the efficacy of classical methods for the diagnosis of meningococcal disease. Rev Med Chir Soc Med Nat lasi. 2014 Apr-Jun;118(2):497-502.

30. Bronska E, Kalmusova J, Dzupova O, Maresova V, Kriz P, Benes J. Dynamics of PCR-based diagnosis in patients with invasive meningococcal disease. Clin Microbiol Infect. 2006 Feb;12(2):137-41. https://doi.org/10.1111/j.1469-0691.2005.01327.x

31. Bryant PA, Li HY, Zaia A, Griffith J, Hogg G, Curtis N, et al. Prospective study of a real-time PCR that is highly sensitive, specific, and clinically useful for diagnosis of meningococcal disease in children. J Clin Microbiol. $2004 \mathrm{Jul}$;42(7):2919-25. https://doi.org/10.1128/JCM.42.7.2919-2925.2004

32. Poppert S, Essig A, Stoehr B, Steingruber A, Wirths B, Juretschko S, et al. Rapid diagnosis of bacterial meningitis by real-time PCR and fluorescence in situ hybridization. J Clin Microbiol. 2005 Jul;43(7):3390-7. https://doi.org/10.1128/JCM.43.7.3390-3397.2005

33. Richardson DC, Louie L, Louie M, Simor AE. Evaluation of a rapid PCR assay for diagnosis of meningococcal meningitis. J Clin Microbiol. 2003 Aug;41(8):3851-3. https://doi.org/10.1128/JCM.41.8.3851-3853.2003

34. Singhi SC, Mohankumar D, Singhi PD, Sapru S, Ganguly NK. Evaluation of polymerase chain reaction (PCR) for diagnosing Haemophilus influenzae b meningitis. Ann Trop Paediatr. 2002 Dec;22(4):347-53. https://doi.org/10.1179/027249302125002010

35. Balganesh M, Lalitha MK, Nathaniel R. Rapid diagnosis of acute pyogenic meningitis by a combined PCR dot-blot assay. Mol Cell Probes. 2000 Apr;14(2):61-9. https://doi.org/10.1006/mcpr.2000.0287

36. Boden K, Sachse S, Baier M, Schmidt K-H, Brodhun M, Husain R et al. 16S rDNA-PCR and sequencing improves diagnosis of bacterial infection of the central nervous system. Open Crit Care Med J. 2011;4(1):44-6. https://doi.org/10.2174/1874828701104010044

37. Abdeldaim GM, Strålin K, Korsgaard J, Blomberg J, WelinderOlsson C, Herrmann B. Multiplex quantitative PCR for detection of lower respiratory tract infection and meningitis caused by Streptococcus pneumoniae, Haemophilus influenzae and Neisseria meningitidis. BMC Microbiol. 2010 Dec;10(1):310. https://doi.org/10.1186/1471-2180-10-310

38. Srinivasan L, Pisapia JM, Shah SS, Halpern CH, Harris MC. Can broad-range $16 S$ ribosomal ribonucleic acid gene polymerase chain reactions improve the diagnosis of bacterial meningitis? A systematic review and metaanalysis. Ann Emerg Med. 2012 Nov;60(5):609-620.e2. https://doi.org/10.1016/j.annemergmed.2012.05.040

39. Costerus JM, Brouwer MC, Bijlsma MW, van de Beek D. Community-acquired bacterial meningitis. Curr Opin Infect Dis. 2017 Feb;30(1):135-41. https://doi.org/10.1097/QC0.0000000000000335 